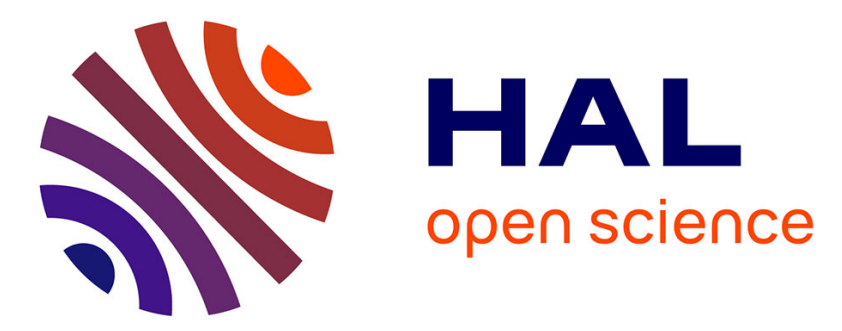

\title{
Real time monitoring of vertical ground deformations during eruptions at Piton de la Fournaise
}

Jean-Paul Toutain, Patrick Bachèlery, Pierre-Antoine Blum, Jean-Louis

Cheminee, Hugues Delorme, Laurent Fontaine, Philippe Kowalsld, Philippe

Taochy

\section{To cite this version:}

Jean-Paul Toutain, Patrick Bachèlery, Pierre-Antoine Blum, Jean-Louis Cheminee, Hugues Delorme, et al.. Real time monitoring of vertical ground deformations during eruptions at Piton de la Fournaise.

Geophysical Research Letters, 1992, 19 (6), pp.553-556. insu-01771594

\section{HAL Id: insu-01771594 \\ https://hal-insu.archives-ouvertes.fr/insu-01771594}

Submitted on 19 Apr 2018

HAL is a multi-disciplinary open access archive for the deposit and dissemination of scientific research documents, whether they are published or not. The documents may come from teaching and research institutions in France or abroad, or from public or private research centers.
L'archive ouverte pluridisciplinaire HAL, est destinée au dépôt et à la diffusion de documents scientifiques de niveau recherche, publiés ou non, émanant des établissements d'enseignement et de recherche français ou étrangers, des laboratoires publics ou privés. 
GEOPHYSICAL RESEARCH LETTERS, VOL. 19, NO. 6, PAGES 553-556, MARCH 20, 1992

\title{
REAL TIME MONITORING OF VERTICAL GROUND DEFORMATIONS DURING ERUPTIONS AT PITON DE LA FOURNAISE
}

\author{
Jean-Paul Toutain \\ Institut de Physique du Globe de Paris, Observatoire Volcanologique \\ de Piton de la Foumaise \\ Patrick Bachelery \\ Départment des Sciences de la Terre, Université de Le Réunion \\ Pierre-Antoine Blum, Jean-Louis Cheminee, Hugues Delorme \\ Institut de Physique du Globe de Paris, Observatories Volcanologiques \\ Laurent Fontaine, Philippe Kowalski and Philippe Taochy \\ Institute de Physique du Globe de Paris, Observatoire Volcanologique \\ du Piton de la Foumaise
}

\begin{abstract}
Tilt changes related to a summit dike emplacement at Piton de la Fournaise volcano have been recorded by a 4 continuously recording electronic tilmeters network during the April 18, 1990 eruption. The real-time processing of these data at the Observatory allows to calculate during the emplacement the relative position of the inflation center from the tilt vectors supplied by the nearby stations. Two main steps have been identified : an initial subvertical intrusion step, followed by a lateral dike migration from the summit cone. This monitoring allows to calculate a high average intrusion velocity of about 0.2 $\mathrm{msec}^{-1}$ which can related to the highly fracturated pattern of the summit area.
\end{abstract}

\section{Introduction}

Forecasting eruptions at active volcanoes requires continuous monitoring of numerous geophysical parameters, mainly using instrumental surveillance networks. Among these, seismic networks are generally considered to provide the most suitable data for eruption prediction, because of the systematic stress release accompanying magma movements. Nevertheless, continuous observations of deformation patterns on active volcanoes, and especially on basaltic shield volcanoes, demonstrate that rapid inflation of the volcanic pile and upheaval of the summit area also occur just before central eruptions as the result of dike injections (Okamura et al., 1985; Lénat et al., $1989 \mathrm{a}$ and b; Delorme et al., 1989). Real time monitoring of vertical ground deformation is therefore expected to provide good short-term precursor evidence for imminent eruptions on such volcanoes, as well as constraining the dike location during an intrusive crisis (Okamura et al., 1988; Trygvason, 1986; Toutain et al., 1991).

In this paper, we will show that an electronic tilt network allows real-time sampling and processing of vertical ground deformations to be undertaken during eruptions at Piton de la Fournaise. With this objective, we will 1) relate the ground deformation patterns linked to the april 18, 1990 eruption of Piton de la Fournaise volcano and 2) establish that electronic tilt monitoring enables in real time, both the detection of magmatic emplacement prior to eruptions, and the tracing of

\section{Copyright 1992 by the American Geophysical Union.}

Paper number 91GL00438

$0094-8534 / 92 / 91 G L-00438 \$ 03.00$ the small displacements caused by dike injection, and therefore 3) demonstrate that such measurements provide a powerfull tool for the location of effusive sites prior to the eruption.

\section{Activity and surveillance of Piton de la Fournaise}

Piton de la Fournaise volcano (Reunion, Indian Ocean) is one of the most active volcanoes in the world, with about 25 eruptions occuring within the last 10 years (Lénat and Bachèlery, 1988 ; Dubois and Cheminée, 1991). On this volcano, monitoring of activity is performed by means of a 5 station clinometric network (Delorme et al., 1989; Delorme et al., in prep), 16 station seismic network (Him et al., 1991) and an 8 station differential magnetism network (Zlotnicki and Le Mouel, 1990). These networks supply radiotransmitted data to a volcanological observatory (OVPF) installed in 1980 (Bachelery et al., 1982). Figure 1 is a map showing the distribution of the OVPF permanent monitoring networks. Due to both the high density of geophysical sensors and the frequent eruptions of the volcano, Piton de la Fournaise therefore provides great opportunities to test the validity of monitoring strategies, such as the use of electronic tilt surveillance methods.

\section{Experimental procedures}

The Piton de la Fournaise clinometric network is composed of 5 radio-transmitted 2-component stations, located within the Enclos Fouque caldera (BOR, DOL, CHA, FLE and SFR stations - Figure 1). Each station is composed of 2 perpendicular electronic tiltmeters oriented radially and tangentially with respect to the summit crater. Sensors are horizontal silica pendulums designed at IPGP by one of us (P.A.B) and sealed to the rock by means of a silica cone. Such an apparatus allows both good mechanical amplification and thermal inertia. Tiltmeters operate by measurement of the motion of a light spot on a cell, with detection limits of about 0.1 microradian and very low electronic drift. These tiltmeters have been found to be insensitive to nearby explosions and the lack of long period parasitic oscillations within seismic frequencies has been evidenced. More precise descriptions of this apparatus can be found in Saleh (1986), Briole (1990) and Briole et al. (1990). Data are sampled at each station every minute by a microcomputer, and consist of the values of the two sensors, of the atmospheric and rock (5 cm depth) temperatures, and of electronic parameters allowing the real-time check of the 


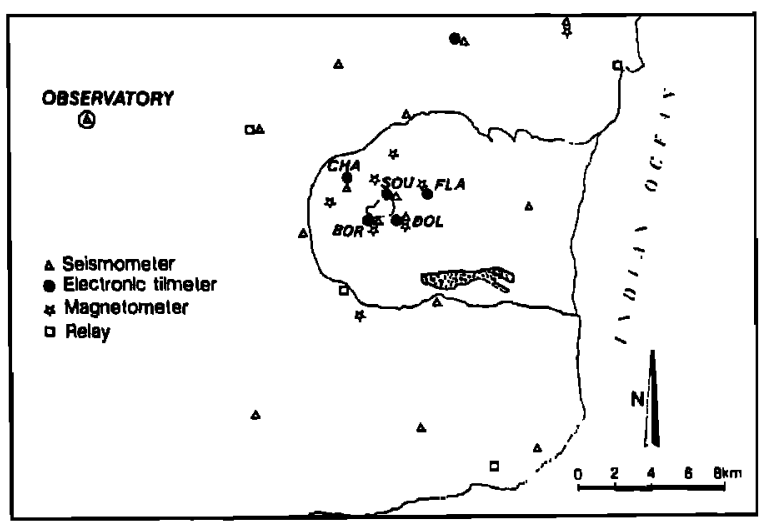

Fig. 1. Distribution of the monitoring networks of OVPF and location of the april, 1990 lava flow.

good working of the station. Blocks of 5 successive data are telemetered every 5 minutes via a relay station, and are therefore available in real time at the Observatory.

\section{Global deformation patterns and reliability of the method}

To check the reliability of this ground tilt measurement method (i.e. to establish that these local measurements are representative of the general deformation of the summit), we will also consider two kinds of deformation data obtained by means of improved geodetic measurements. Long-term horizontal and vertical displacements of 13 benchmarks around and into Dolomieu crater have been determined by EDM measurements and trilateration surveys. Long-term tilts have also been calculated using precise levelling methods (known as "dry tilt" method, see Fiske and Shepherd, 1990) for four stations distributed on the summit zone.

Figure 2 displays horizontal and vertical displacements (computed assuming that the Enclos Fouque caldera rim remains stable) of reference points in the summit area for the period March-July, 1990. Horizontal deformation indicate significant and coherent movements of the marks in the eastern part and very limited and coherent movements of the marks in the western part.

Figure 3 displays in contour-lines the general deformation of the summit zone, that has been constructed from both vertical displacement of the 13 summit benchmarks and observed tilt variations measured at the four "dry-tilt" stations in the summit area. This reconstruction seems reasonable, based upon the good agreement between the two sets of data.

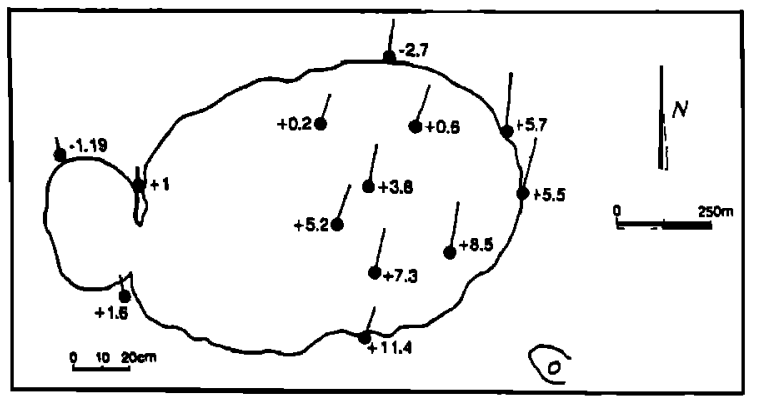

Fig. 2. Direction and value of horizontal (plain line, see scale on the figure) and vertical (bold numbers, in $\mathrm{cm}$ ) displacements of benchmarks (period Feb-July, 1990). Precision is of about $1 \mathrm{~cm}$.

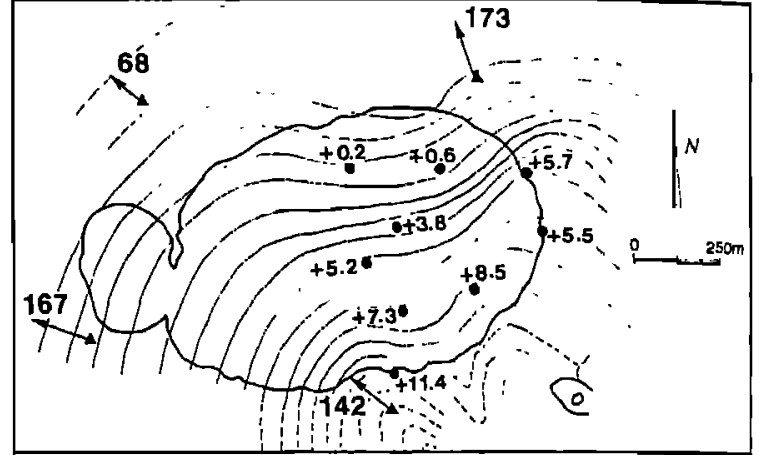

Fig. 3. Contour-lines showing the general deformation of the summit area. Contour-lines have been extrapolated from geodetic (values in $\mathrm{cm}$ ) and dry-tilt data (plain lines, bold numbers, values in microradians).

These results suggest a general upheaval of the southeastern part of the summit zone, with a general N.W. tilt of the Dolomieu crater area. The slight curvature of the contour-line in the center of the "deformation map" (fig. 3) is not well defined but suggests a dike-induced deformation pattern.

Table 1 lists values of the direction and intensity of slope changes in the summit area, as determined by electronic tilt and precise levelling methods. Table 1 shows that very good agreement between "dry tilt" and electronic tilt data is obtained, especially concerning tilting directions, with differences lower than 3\%. Significant differences can however be observed for intensity values between the methods (from 22 to $40 \%$ ). These latter probably are the result of the slightly different periods of investigation considered, and/or of soil heterogeneity effects that might cause different intensities of tilt from one lava block to another.

\section{General patterns of the April, 18 eruption}

The April 18, 1990 enuption at Piton de la Fournaise was preceded by about 15 days of increasing seismicity. Events of the enuption have been recorded by OVPF as follows (in minutes): 1) 125 to 174 : swarm of 4 low energy earthquakes 2) 186 to $206:$ swarm of about 40 shocks 3) 206 to about 240 : seismic crisis, with almost continuous shallow shocks 4) about 243 to 530 : lower frequency seismicity and 5) minute 530 : opening of eruptive vents indicated by generalized harmonic tremor (SEAN, 1990). Lava outpoured in the southeastern area of Enclos Caldera (Figure 1), accompanied by both vigorous fountaining and lava flows, with an estimated emission rate of about 20 to 30 cubic

Table 1. Comparison of azimuth (D, degrees) and intensity (I, microradians) of summit tilt supplied by electronic tilt and precise levelling methods.

\begin{tabular}{ccccc}
\hline & $\begin{array}{l}\text { Dry } \\
\text { tilt }\end{array}$ & \multicolumn{3}{c}{$\begin{array}{l}\text { Electronic } \\
\text { tilt }\end{array}$} \\
\hline & D & I & D & I \\
BOR & 292 & 167 & 288 & 130 \\
DOL & 311 & 142 & 314 & 190 \\
SOU & 343 & 173 & 332 & 290 \\
\hline
\end{tabular}


meters per second. Lava emission lasted until May 8, with an extruded volume of aphyric basalt of about $8 \times 106 \mathrm{~m} 3$ (SEAN, 1990).

\section{Real-time monitoring of the April, 18 eruption}

Considerable vertical deformation is recorded from minutes 213 to 230 , with two distinct movements (minutes 213 to 224 and 225 to 230 ). Figure 4 displays the azimuth and value of tilt (in microradians) as a function of time for the 4 working stations (FLA being out of action). Figure 4 shows that the most significant changes occur at the stations nearest the summit (up to 400 microradians as seen by the tangential DOL tilmeter), whereas the furthermost station (CHA) displays very much lower changes (3 and 5 microradians for the tangential and radial tiltmeter, respectively). In this figure, increasing values of radial tilt coincide with central inflation, whereas decreasing values can be correlated with central deflation. This suggests a short wavelength deformation due to a central and shallow input of magma in the summit cone leading to a general inflation of Dolomieu area (in accord with geodetic data), followed by a strong deflation of this area. One can note that CHA station indicates during the summit inflation phase a slight subsidence at a distance of about $2 \mathrm{~km}$ from the summit. This could indicate either a normal relaxation movement or a pressure decrease within the magma batch involved in the eruption.

The relative position of the inflation center between minutes 213 and 230 has been calculated in real-time from the tilt vectors supplied by the 3 summit-area tilt stations, and is displayed in figure 5. Values from CHA have not been used for these calculations, owing to the small scale of the changes observed at this station (figure 4).

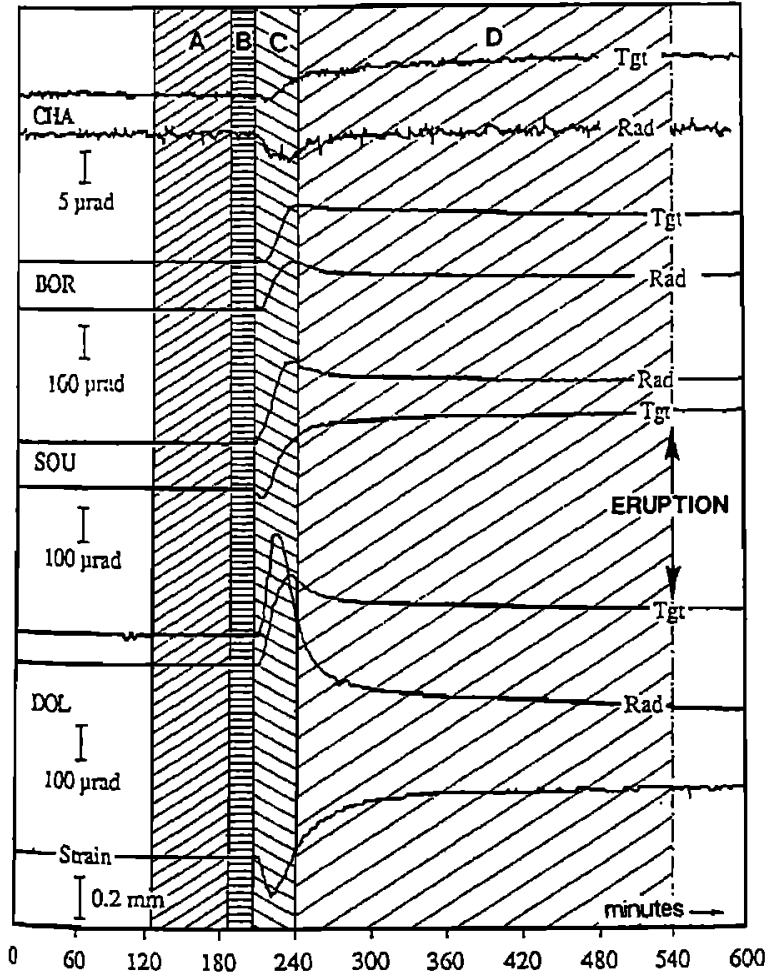

Fig. 4. Deformation recorded by the 4 electronic-tilt and 1 strainmeter network between minutes 000 and 600 on April 1990. Station locations are shown on figure 1. The hached weas are related to the seismic periods described in text.
The distribution of inflation centres distribution shown in figure 5 allows the two main phases of the deformation pattern to be distinguished : 1) from minute 213 to 224 , a central inflation located beneath the northeastern part of Dolomieu crater, which is probably due to a sub-vertical dike intrusion and 2) from minutes 225 to 230 , a migration towards the south-east of inflation centers associated with a rapid deflation of the summit area (as seen from the decrease of the radial component at SOU, DOL and BOR stations figure 4). Because electronic tilt stations are lacking in the southern area of Enclos caldera, it was not possible to document the migration of further inflation centers. According to the regular decreasing patterns of summit tilt stations after minute 240 , however, and to the well-defined spatial trend of inflation centers between minutes 225 and 230 (figure 5), one can infer that migration was continuing towards southeast. This prediction was fulfilled by the onset of the eruption at minute 530 in the southeastem area of Enclos Fouque (figure 1).

\section{Velocity of dike injection}

The precise temporal identification of the dike emplacement during this intrusive crisis allows the detrmination of dike migration velocity within the volcano. Assuming a vertical displacement of $1.5 \mathrm{~km}$ for the dike (this is a reasonable value expected for the depth of the magma pocket as determined from seismic data), and taking into account the 12 minutes duration necessary for this vertical migration, we can calculate a mean vertical velocity of about $2 \mathrm{~m}$. sec-1. The migration phase (minutes 225 to 230 ) allows us to calculate a lateral velocity of the dike within the summit cone at about $2.3 \mathrm{~m}$. sec-1. These two values are quite high with respect to the calculations of Okamura et al. (1988) for the velocity of dikes emplaced during the Pu'oo eruption $(0.15 \mathrm{~m}$. sec- 1$)$. These authors have however also documented velocities of up to $0.6 \mathrm{~m}$. sec-1 as the result of local pulses due to the contact of the growing dike with small shallow magma pockets.

No definitive interpretation can be made in our case, but it must be noted that the surface tectonic pattern of Piton de la Fournaise (very dense network of radial and tangential fissures) could explain the high velocity of dike migration within the summit area.

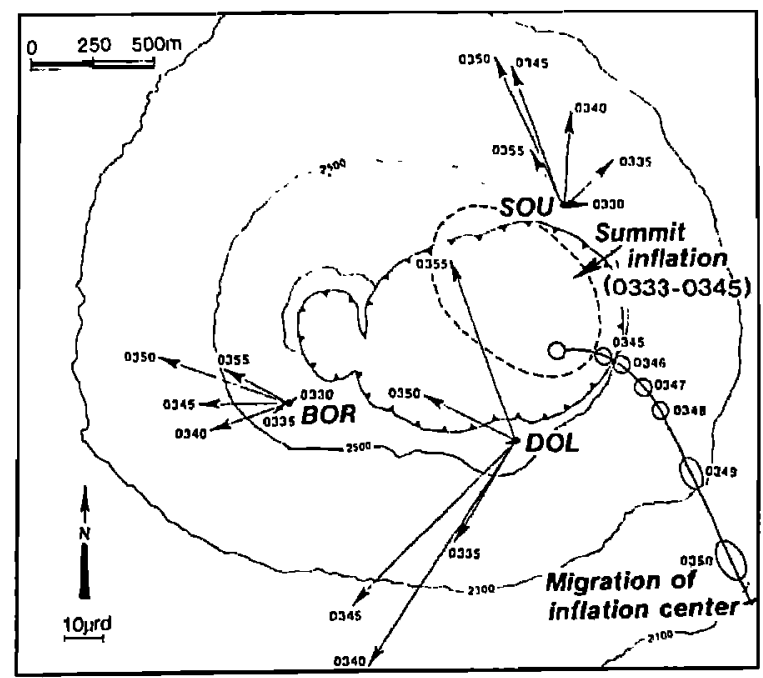

Fig. 5. Map of the summit area of Piton de la Fournaise showing migration of the inflation center, calculated using tilt vectors from the Dolomieu, Bory and Soufrière stations. 
In conclusion, assuming a total migration duration of 317 minutes (minute 213 to 530) for an horizontal distance of about $4000 \mathrm{~m}$, we can suggest an average velocity for the intrusion of $0.21 \mathrm{~m}$. sec-1.

This value is in good agreement with estimations of Briole (1990) for the average extrusion rate of dikes at Piton de la Fournaise $(0.21 \mathrm{~m}$. sec-1). It must be noted that the migration of the dike has also been accompanied by a significant change of both the general pattern and the spectral character of seismicity with respect to the previous inflation phase. Indeed, this latter phase showed normal shallow high frequency earthquakes swarms whereas the migration phase was characterized by wavetrains with a considerably lower frequency (roughly $1 \mathrm{~Hz}$ ).

\section{Conclusion}

Electronic tilt measurements of the april 18, 1990 eruption of Piton de la Fournaise volcano allows the monitoring of vertical deformation patterns caused by the subvertical intrision, and successive lateral migration of a dike in the summit cone. Such a monitoring system, including real time data acquisition and processing (with real-time mapping of inflation centers) is now operating at Piton de la Fournaise Volcanological Observatory, and allows the location of the eruptive site to be predicted. This is, in the context of Piton de la Fournaise, a significant new tool for mitigating the effects of effusive eruptions.

Acknowlegements. The authors are grateful to A. Legros for drawings, and to A. Gerente for field support during the eruption. Special thanks to B. Mac Guirre for his critic review of the paper.

\section{References}

Bachelery P., P̈.A. Blum, J.L. Cheminee, L. Chevallier, R.Gaulon, N. Girardin, C. Jaupart, F. Lalanne, J.L. L̇e Mouel, J.C. Ruegg and P. Vincent, Eruption at Le Piton de la Fournaise volcano on 3 Ferbruary 1981. Nature, 297, 395, 1982.

Briole P, Mesure de déformations du sol de volcans et zones sismiques. Exemples de développement et de mise en oeuvre d'outils de mesure. Interaction mesuremodélisation. Thesis, Univ. Paris 6, 1990

Briole P., P.A. Blum, G. Nunnari and G. Puglisi, Inclinometric measurements on Mount Etna, Italy. Method and first results. J. Volcanol. Geoth. Res. in prep.

Delorme H., P. Bachelery, P.A. Blum, J.L. Cheminee, J.F. Delarue, J.C. Delimond, A. Hirn, J.C. Lepine, P.M. Vincent and J. Zlotnicki, March 1986 eruptive episodes at Piton de la Fournaise volcano (Reunion Island). $J$. Volcanol. Geoth. Res., 36, 199, 1989

Delorme H., P.A. Blum and A. Him, High resolution monitoring of an intrusion-eruption episode by tiltmeter and seismometer arrays (Piton de la Fournaise Volcano). Bull. Volcanol., submitted
Dubois J., J.L. Cheminee, Fractal analysis of eruptive activity of some basaltic volcanoes, J. Volcanol. Geot. Res., 45, 197-208, 1991.

Fiske R.S. and J.B. Shepherd, Twelve years of ground-tilt measurements on the Soufriere of St Vincent, 1977 . 1989. Bull. Volcanol., 52, 227, 1990

Hirn A., J.C. Lepine, M. Sapin and H. Delorme, Episodes of pit-crater collapse documented by seismology at Piton de la Fournaise. J. Volcanol. Geoth. Res., 47, 89-105, 1991

Lénat J.F., P. Bachèlery, Dynamics of magma transfer at Piton de la Fournaise volcano (Réunion Island, Indian Ocean).-In : Chi-YU and R. Scarpa Eds.- Earth Evolution Sciences. "Modelling of volcanic processes", Fried. Vieweg and Sohn, Braunschweig/Wiesbaden, pp. 57 - 72, 1988

Lénat J.F., P. Bachèlery, A. Bonneville, P. Tarits, J.L. Cheminee and $H$. Delorme, The december 4, 1983 to february 18, 1984 eruption of Piton de la Fournaise (La Reunion, Indian Ocean): description and interpretation. J. Volcanol. Geoth. Res., 36, 87, 1989

Lénat J.F., P. Bachèlery, A. Bonneville and A. Hirn, The beginning of the 1985-1987 eruptive cycle at Piton de la Fournaise (La Reunion); new insights in the magmatic and volcano-tectonic systems. J. Volcanol. Geoth. Res., $36,209,1989$

Saleh B., Développement d'une nouvelle instrumentation pour les mesures de déformations. Applications au génie civil. Thesis, Univ. Paris 6, 214, 1986

SEAN, Dike injection, then eruption from fissure vents near $S$ caldera wall. SEAN Bull., 15-5, 4, 1990

Toutain JP., Bachelery P., Blum PA, Cheminee $\mathrm{JL}$ and $\mathrm{H}$. motions at Piton de la Foumaise volcano. Proceedings of the 3 rd conference on active volcanoes and risk mitigation, Napoli, 1991.

Trygvason E., Multiple magma reservoirs in a rift zone volcano. Ground deformation and magma transport during the september 1984 eruption of Krafla, Iceland. J. Volcanol. Geot. Res., 28, 1-44, 1986.

Zlotnicki J. and J.L. Le Mouel, Possible elektrokinetic origin of large magnetic variations at La Fournaise volcano. Nature, 343, 633, 1990.

P. Bachèlery, Département des Sciences de La Terre, Université de la Réunion, 15 avenue René Cassin, $97489 \mathrm{St}$ Denis cedex, France.

P.A. Blum, J.L. Cheminé and H. Delorme, IPGP, Observatoires volcanologiques, 4 Place Jussieu, 75252 Paris cedex 05, France.

L. Fontaine, Ph. Kowalski, Ph Taochy and J.P. Toutain, Observatoire Volcanologique du Piton de la Fournaise, 14RN3, Km 27. 97418 La Plaine des Cafres. France.

(Received : November 14, 1991

Revised : February 10, 1992

Accepted : February 13, 1992) 